A major purpose or tne I ecrirical Information Center is to provide the broadest dissemination possible of information contained in DOE's Research and Development Reports to business, industry, the academic community, and federal, state and local governments.

Although a small portion of this report is not reproducible, it is being made available to expedite the availability of information on the research discussed herein. 
LA-UR $-84-2436$

$$
\begin{aligned}
& i \because i \quad \therefore \% i . \quad\langle i \\
& \text { 1..:-ii.,--i,.....? } \\
& \therefore .1 \cdot 3 \%
\end{aligned}
$$

IIIL STUNIES ON EXPLOSIVELY DRIVEN CRACKS UNDLR C.ONFINING IN SITU STRESSES

AuIHOH(S) K. R. Y. Simhd, H. L. Fourney, and R. D. Dick

SUHmiriliili) 25th U.S. Symposium on Rock Mechanics

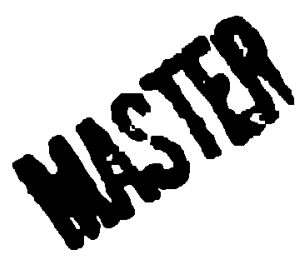
Northwestern University, [vanstion, II June $25-27,1984$

\section{IMST I MIFK}

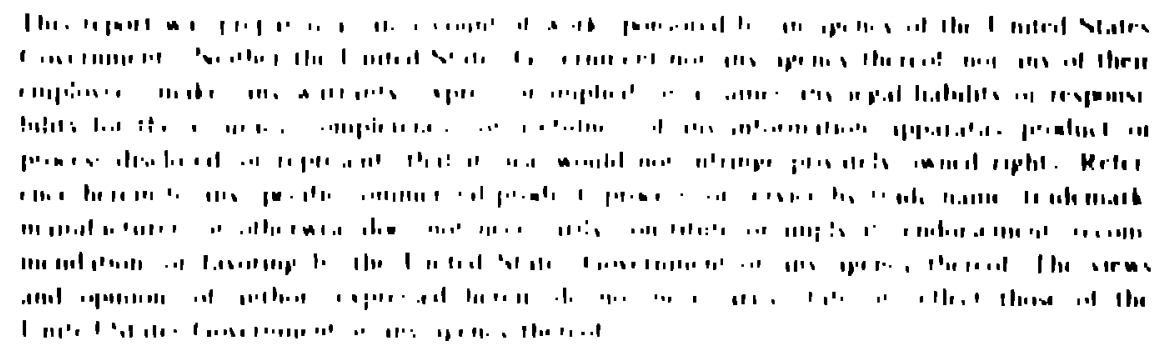

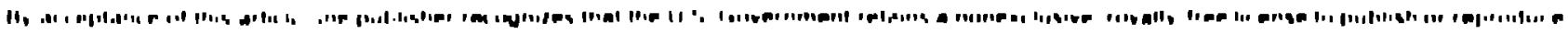

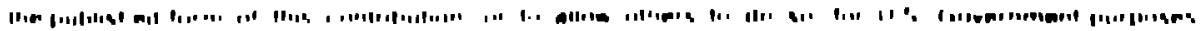

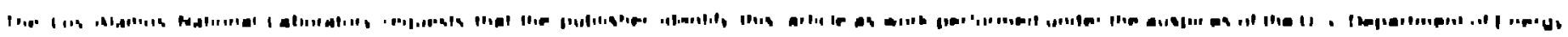




\title{
STUDIES ON EXPLOSIVELY DRIVEN CRACKS UNDER CONFINING IN-SITU STRESSES
}

K. R. Y. Simha and W. L. Fourney Mechanlcal Englneering Department University of Maryland College Park, MD 20742 and

RIchard D. Dick

Les Alamos National Laboratory Los Alamos, New Mexlco 87545

\begin{abstract}
Successful explosive gas well stinjlation requires a thorough understanding of explosively driven cracks under confining in-situ otresses. In a previous paper (S1mha, et al 1983) the problew of explosively driven cracks wag experimentally investigated to reveal the leatures of crack propagalion. It was observed that the explosively driven crack propagation is the result of cwo different but overlapping phases. The first phase involving the initiation and early time crack propagation is entirely governed by the explosively Beneraced stress translenta. The rapldly deraylng otress transients then lead to the second phase of chack propagation largely controlled by the in-aitu atresses. The purpose of this paper ls to more fully underctand the characteristics of the first phase concerning the initiation and early time propagation of explosively driven cracks. Experlaents are conducted wlth plastic models under blaxlal compressinn and the dynamlc curitl in observed with a high sperd maleiplo spark iap camara of tho Cranz-Schardin type. The experimeneal observalions are utilized to propose analytical models of crack Indetation under explosier londing io nid in the design of multiple frarturling neccesary for bucessiul application of modern well at lmulatlor technlques.

\section{INTRODUCTION}

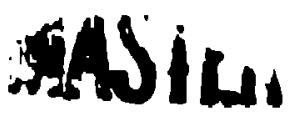

Tha rver prowlng need for oll and mecural gas has led to several new somres of hydrucarbon furla that tequler novel and often very

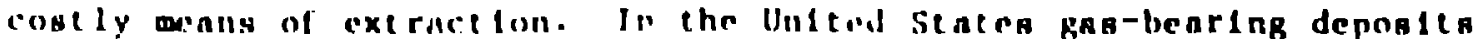

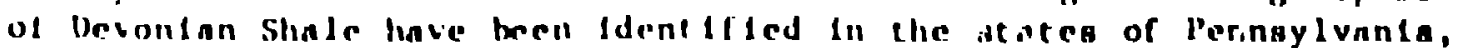
Keneucky and Heat Virglinin along the Appalachlan busin. Vint as theae deponles are, only a leu ol the many tlolds have proved io be cconomiEally viable. The key tactor lor "uell to be puccearul in that
\end{abstract}


the shale ourrounding the well bore be fractured to promote gas flou into the well bore. Touards this end varlous tectniques have been actempted to stimulate vella. Stimulation by hydraulic fracturing has been woderately successful in this regard. Hovever in recent times explosive otimulacion has been enthusiactically investigiced, although In some Instances, the flow rated have acturlly been oubstantialiy reduced.

Th1s has baen atcributed to a conbination of factors including etress caging and excessive fragnentaticn causing crank closure by fines. However among other factore the succeseful application of explosive stimulation Inrolves the phenomenon of dynamic cracic propagation in the presence of confining in-oltu stresses. Spectfically, the ploblew Involves linking the well bore to a pre-existing fiacture network were it becomes necessary to drive cracks over long lengrho as well a maintain control over their patho. While the crack iength 1. largely determined by the beret.ole pressure generated by the exploa 1 on and the consequent gas flou Into the propagating cracks, the crack pach 1o significantly dependant on the extating in-sicu otregers. In 1980 Harpinak1, et al described the results of tesco conducted at the U. S. Department of Energy' Nejada teot fite to axaal ne the effecte of in-aitu atress varlacion on fracture. Earier in 1976 Dally and Fourney reported on c elaplifled model to predict tne crack curvature under a uniaxial stress fleld. Recently, an experimental Invectigaticn wa conducted to extend t.lis model to the general cave of a biaxial otrees fielc (SImha, et al 1985). In the above invertigation the general features of explosiveiy driven cracks were discuesed wth the enhasis on the nature of propagation in the presence of confining in-eltu ecreasea. The purpose of thlo paper 10 to reviev the work In the light of additional experimenta and apecifically addreas the problex of crack Initiation and early time f-opagation. These are the key lasue involved in rechulques auch as callered pulse loading and have otill not been complctely underatood. Another purpose of this paper is co utilize the experinental observatione to propose an anajycical odel of creck iniciacion under exploaive loading.

\section{EXPER IMENTAL INVEST IGATION}

Transparent plastic wae ctilfzed in rhe exferimental invectigation. The modele were nominally $205.4 \mathrm{za}\left(12^{-}\right)$equare and the cracke vere driven frou a 28.1 an $\left(1-1 / 2^{-}\right)$borchole. The biexial load wa applied with a epecially farricated device capable of applying compreasion up to $4500 \mathrm{~kg}\left(10,000\right.$ 1be). F1gure: show a $50.6 \mathrm{~mm}\left(2^{-}\right)$th $1 \mathrm{cix}$ nlexiglas odel In the biaxial loading tevice. Thip device perwitce the blaxfal acresees to be varied independently froe zero up to abcut $25 \mathrm{~kg} / \mathrm{ca}^{2}$ ( $350 \mathrm{pal}$ ). The atreas ratio wan varlad by adjusting the chlcknease of the olde ohlma. Plexiglas onlas vere uned co redure ecrees rave reflectione and further reduction of wove reflectiona reaulted upon providing rubber pade betueer. the ahima and loading 


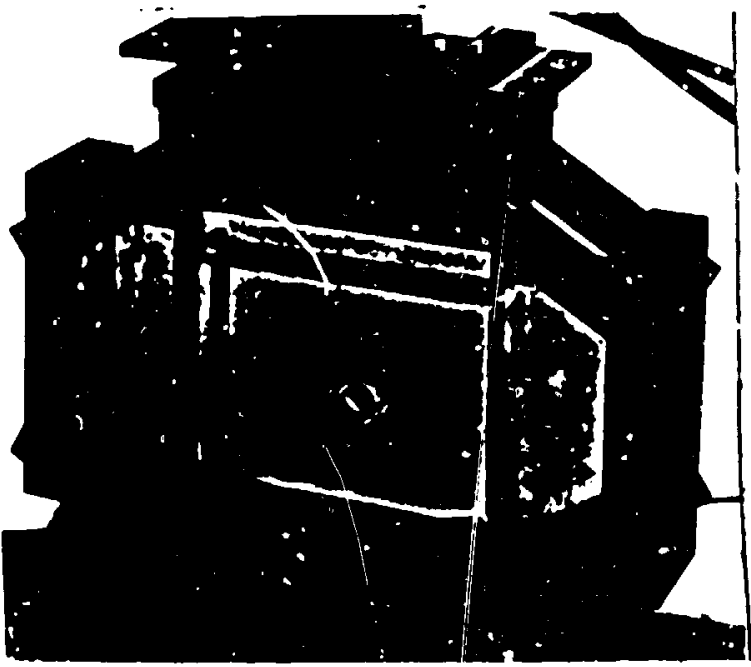

frame platens. The models were charged with up to $500 \mathrm{mg}$ of explosives consisting of elther PETN or a mixture of PETN and a propellant obtalned from the Kinetech Corporation of Sacramento, Callfornia. Flaw sites on the borehole wall were simulated by making small notches on the borehole wall. The borehole was notched at two diametr1cally opposite locations to $11 \mathrm{mlt}$ the number of cracks co two. The notches were all $1.6 \mathrm{~mm}$ wide and $3.2 \mathrm{~mm}$ deep. The charges were detonated while the models were in

Figure 1 Plexiglas model in the blaxtal loading frame
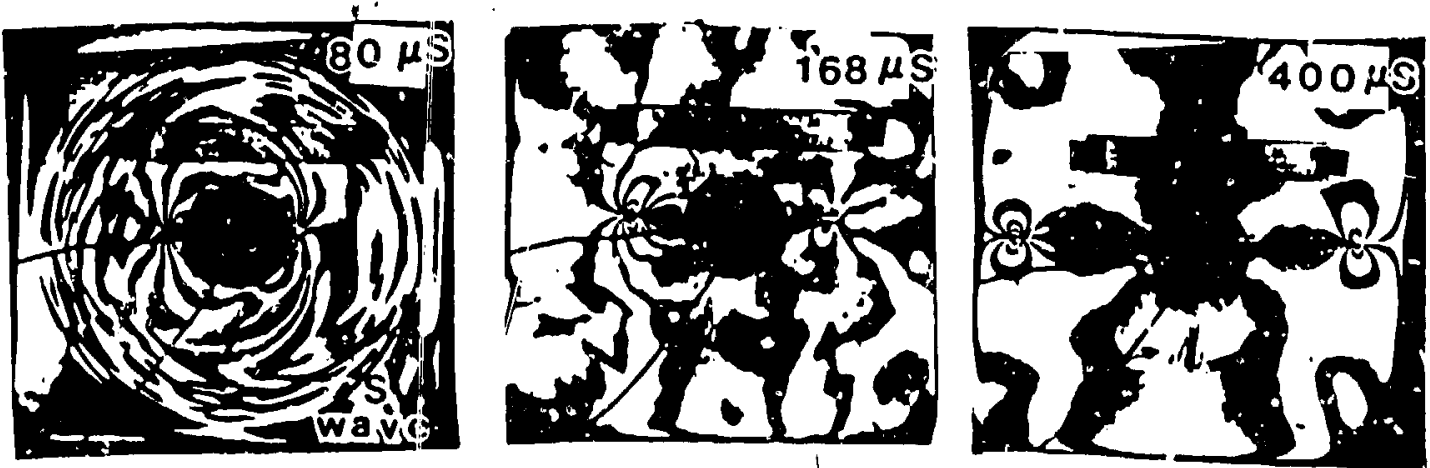

a) Hydrostacic In-situ atress
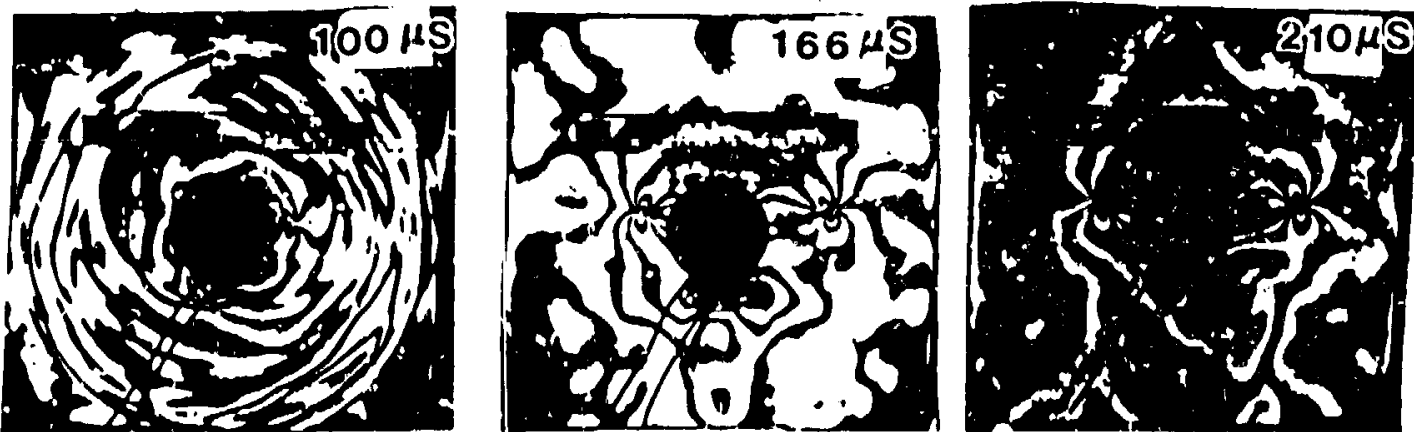

b) Non-hydrostat1c In-situ stress

Figure 2 High speed plctures of explosively driven cracks

the fleld of view of a high specd miltiple spark gap camera of the Cranz-Schatdin cype. This camera la rapable of elxteen plctures at framing rates as high as 850,000 per second and permits the otudy of high speed phenomena. The rccording of borchole pressure generated by 
the explosion was achieved by the use of Kistler plezoelectric transducers in confunction with the Nicolet digitel oscilloscopa. A pressure containment device consisting of two circular steel caps held by a through bolt was used to retain the explosive gases in the borehole. For more detalls on the experimental arrangement the reader is referred to the previnus paper (3lmha, et al 1983).

Figure 2 show some high speed plccures taken by the CranzSchardin camera. For the case of explosively drjven crasks in a model subjected to a state of hydrostatic compreseion, the cracks propagate radially otralght and for other cases the cracks curve. A series of cests were conducted with different 1n-situ stress levels. The experimental lata was utilized to underatand the mechanica of initiation and early time phenomena involved in explosively driven cracks as discusned in the next section.

\section{INITIATION AND EAPLY TIME PROPAGATION OF EXPLOSIVELY DRIVEN CRACKS}

If the concepts of static fracture mechanics are utilized, then cracks Inltiate whenever the stresp Intensity factor. $K$, exceeds a certain critlcal value, $K_{I C}$, termed as the fracture l sughness. Streso Intensity factors and fracture toughness values have ieen determined for a varlety of crack oltuations and materialo respectively (see for example Rock Practure Mechan1ce Ed. Rosemanith, 1983). For the purpose of computing SIF it 18 assumed that the crack 18 completely pressurlzed to the borehole value. Accordingly for the present borehole/notch configuration the critical pressure necessary to drive the cracks in pleriglas model is about 11.5 MPa for which the fracture coughness value 18 $2 \mathrm{MPa} \sqrt{\mathrm{m}}$. Thcoe values issume that there 18 no effect of the prestress on the fracture iniliotion process. While thio desumption to not utrictly velid, in the present investigation. the prestres magnitudes dic not exceed about $20 \%$ of the peak dynamic borehole pressure and it wo found that thelr cffects were only 1mportant in the late time crack propagation (S1aha, et al 1983). The hoop otreso in the vicinity of an explosively loaded borehole plays an Important rale in crack inltiation. If we now focus our attention nn the hoop stress at the polnt of crack initiation; $1 . e ., 9-0, \pi$ and $r$ - a, the value lo

$$
\sigma_{0}-\sigma_{\theta}^{d}-\sigma_{1}+3 \sigma_{2}
$$

In the abore equation oud represents the dynamic hoop stress caused by the explosion and $\sigma_{1,2}$ are the in-altu utresses. While $\sigma_{\theta} d$ can be determined for the ase of radiul eymmecry, a Beneral. solution Is ratice formidable. A detalled discusion of this appect in given in the previoualy mentioned reference. 
We can anticipate that fracture intelacion depends on this hoop stress in a manner that will involve the otress intensity factor at the notch tip. Accordingly from Equation (2) the additional borehole pressure required to overcome the effect of In-situ prestress is $\left(3 \sigma_{2}-\sigma_{1}\right)$. In the present Invastigation rhis vase ranged from zero to as high as $6.9 \mathrm{MPa}$. Yet no algnificant colzelation was observed between this value and the explosive presicre necesaary to initiate the cracks. This points to the extremely transiest nature of crack Initiation wherein the dynamic otress intensity factor due to the rransient borehole pressure becomes the aeclolve factor. F1gure 3 shows the crack tip position vo time for a' rehole pressure loading shown in the same figure. In this test the principal blaxial in-altu otresses were $1.27 \mathrm{MPa}$ und $0.9 \mathrm{MPa}$ with. the larger strass acting to close the crack. The borehole pressure reached a maximum of $17.9 \mathrm{MPa}$ follwwed by decaying oscillations due to the combined ejfect of shock wave reflections inside the borehole and gas venting thr ugh the cracks. The crack tip plot in Figure 3 when extrapolated backwards Indicated a fracture Initiation time around $60 \mu \mathrm{\mu}$. At thje instant of tlme the borehole pressure was about $13.8 \mathrm{MPa}$, about 147 more than the otatically predicted value. Presently another polymeric material called Hnmalite 100 tas achleved a prominent position in dynamic photoelastic otudies of fracture phenomena. Th1s material has a otatic fracture toughness of approximetely $20 \%$ as that of plexiglas hich translates to a critical borehole pressure of 2.3 MPa for the present model configuracion. Flgure 4 shows the results obtalned whth this mute-ial when there das no prestress applied to the rodel. Th. cracks Intelated at $5 \mathrm{C}$ w when the brecisle pressure was $8.3 \mathrm{MPa}$ and itt11 rising. Thlo corresponds to almost ihree times the value pradilted by static fracture toughness concepts.

In conclusion the dynamle photoelastlc experiments furnished valuable trolght into the prublem of explosively driven cracks from a flaw sice. It was conslatently observed in all the testa that the dynamic preasure required to Initiace the cracks are greater than the values predicted using static fracture toughness concepts. In some experiounts it was observed that the cracks inltiated during the loading phase when the borehole preseure was still rising while in other tests it wa observed that the cracks initiated during unloading after the presaure had reached lia peak value. However no definite conclusion can be drawn regarding the fracture initation time except that the cracks walt intil they are charged with oufficient energy to i vercome the Initial resintance of the materiaj around the notches. Theje results once again suggesl otrongly that dynamic crack propagation from an explosively loaded borehole depends on the entire pressure hlstory and not just the inotantaneous presaure value. The experimental results obtalned so far promptrd formulating an analyt cal model nf explosively driven crack iniclation given in the next acction. A detalled description of the model lo given lil another report (SImha, ct al 1984) and here it will be only briefly oummarlized. 

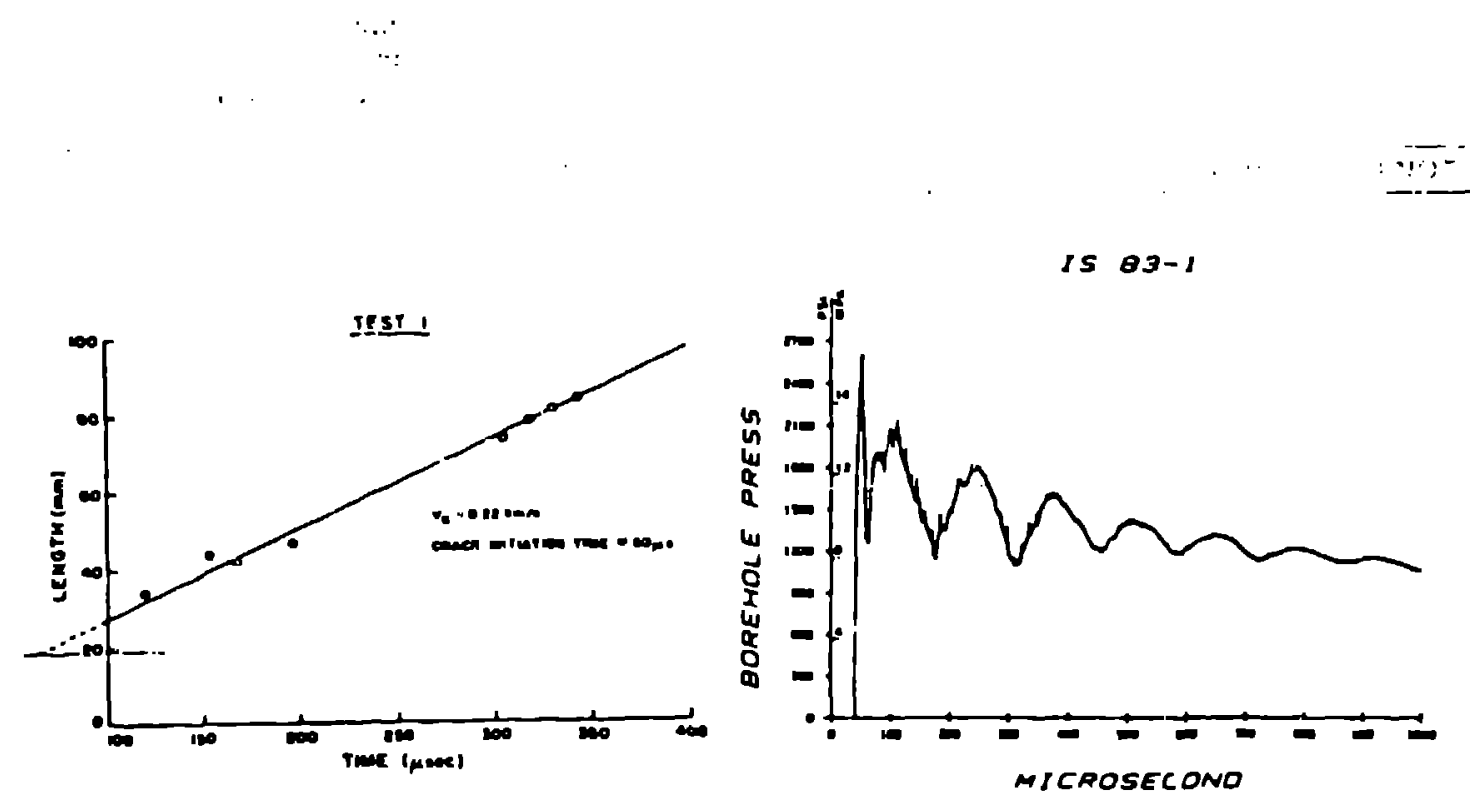

rigure 3 Explosively driven crack grcwlh in plexiglas
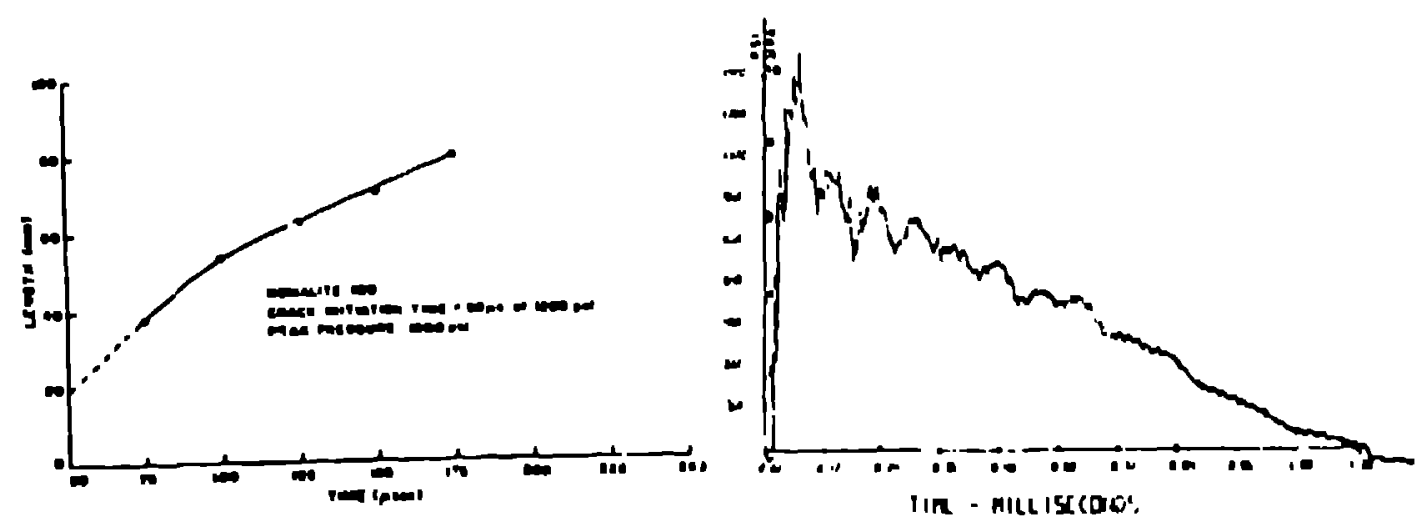

Figure 4 Explosively driven crack growth in Homalite 100

ANALYTICAL MODEIING OF EXPLUSIVI LOADING

In recent years the tallored pulge loading has emerged as an entiring concept for achleving multiple fracturing for well ot mulation. The basic Idea is to generate a borehole preasuce high enough to Initlate as many radial fractures as possible but not too high co crush the rock. Intultively thls lmplies a preasure loading history that iniclaliy rises steeply hut then malntalns a value jusc enough to ovrecowe the crack resistance of the rock. In this context the subject of fracture mechanlce provideo miny useful guldelines. There la a general tindency ts rely on statlc fracture ashanlcs concepts to predict aynamic fructure phenomena such as explosively induced fractura. Tila is not surprising due to the ease with inilch one can establish th: ralevant aterlal parametere euch as fracture 
toughness, KIC or the critical crack opening displacement. While these parameters have been weli teated for stat1: loading conditlons, It has not been verifled whether these results can be extrapolated into the dynamic loading reglme. In general it can be sald that atatic approaches provide incomplete guldelines for estimating the outcome of a dynamic fracture event. There is a definite experimental evidence as seen here and by other Investigators (Grady and Hollenbach 1977) that loading rate affects the frocess of fracture initlation significantly.

Shockey, et al 1983, have assessed ceveral exigting dymamlc fracture criterla experimentaliy and concluded that for crack initiation, the dynamic otress intensity factor must equal or exceed the fracture coughness val.e for a certain minimun time. In the present papez an attempt is made to model crack initiation directly on the basis of the borehole pressure loading hiatory. The modeling is gulded by the experimental observations and basic dynaml: fracture mechanics and for core detalls the reader 1 s leferred to the reporc.

Tentatively one can postuiace that fracture Instablity is possible only when the energy release rate exceeds the static crack realstance. Secondly it can be postulated that there is a definite tine lag before the onset of fracture instabllity after reaching the above condition. Further during this time lag energy is fed into the process zone to overcowe the dynamlc crack resistance of the material for a given erack specd. During this phase there is some subcritical crack growth that occurs with the crack growing non-unitormly. The transition from subcitical crack growth to the final fracture instabflity depends on the material response to dynamic losding. This transition can be conventently modeled by an apparent increase in the crack length by $\Delta a$ due to the formation of the process zone. This impliea that the subcritical crack growth ieed not actually take place physlcally. It ls only the occurrence of irreveralble processes around the crack thp that makes the crack behave an if it were longer than ita physical atze. Th1s approach was orlginally gugseated by Irwin, 1958, to account for crack tip plasticlty effects in metalo. With regard to multiphase oystems such as rocks and ceramico the oltuation tecomes more complex. The microcrack procese zone in these materials 1o chardcterlzed by the local fracture toughness which uncles algnificantly from point to polnt. This varlation con make the microcrack process zone extend to considerable lengths from the crack tir. Although there ls much evidence of a microfracture procest zone In rocks, comparatively little is ks. wn about its shape and ofze. All thess losues pose problems in predicting the onset of dynamic fracture Instablity. In the context of dynamic loading, finite times assoclated with crack inltiation and early clme crack accoleration depend on the formation of process zone of the correct shape and aize. At excremely high loading rates, as may be the caue in explusive loading, the time for the accelerating phase 18 of the same order as that required to achleve fracture initlation [Grady and Hollenbach 1977). The foregolng cencepts were utilized in formulating a fracture 
Initiation criterion. The criterton was developed from the following two fundamental requirements.

$$
G^{d y n}>G_{I C} \text { or } R_{C}: \int_{0}^{\Delta a} G^{d y n} d a>\int_{0}^{\Delta a} R_{C} d a
$$

Using the above conditions it 18 possible to establish a relationship between the time delay and dynamic fracture coughness. If we assume da $=Q_{n} t^{n}$ and $R_{c}=$ constant, then the time delay, $T$, for $n-1$ is given by the following integral equation

$$
K_{I d}=\sqrt{\frac{1}{T} \int_{0}^{T} k^{2} d t}
$$

The above equation ascribes a root mean oquare calculation fo: $K_{I d}$ the dynamic fracture toughness. Thls equation was applied to the Homalite 100 model to estimate the dynawic fracture toughness at the loading rate observed in this test. The experimental data is the save as presented earlier In Figure 4. In this experiment the fracture Instablity occurred at 50 wo when the borehole prepoure way 8.2 HPa and rising. The average rate of pressure rise was $0.2 \mathrm{MPa} /: 18 \mathrm{ec}$ corresponding to a $\mathrm{K}$ of $0.03 \mathrm{MPa} / \mathrm{m} / \mathrm{usec}$. Agouming a btat fe fracture toughness of $K_{I c}=0.4 i \mathrm{Ma} / \bar{m}$, the time delay for Equation (3) 13 approximately 27 us. Ut.11zing this value in (3) gives $\mathrm{K}_{\mathrm{Id}}-.51$ MPa/m. Thls represents a $17 \%$ increase in 1ts fracture toughness from the utatic value.

In conclusion the problem of fracture instablity under transient loading conditions depends on the materlal behavior at high otrain rates. When the flaw size is large the Instabliticy lo also governed by the relative duration of the load and the time that it takes for the otress wave to traverse the length of the crask. In the context of explosively driven fracture utilized for well otimulation or controlled blasting operations, the more lmportant parameter is the pressure time hlstory exerted on the borehole wall. As developed in the fracture instability criterion the pressure history or equivalently the otress intensity factor hlstory determines whether or not a crack propagates from a borehole. It lo also possiblt employlng the analysis developnd in this paper to qualitgively understand the time delays Involved with-difierent types of pressure loading. 


\section{CONCLUSLONS}

An experimental Investigation has been conducted to study the influence of confining in-situ stresses on explosively driven cracks from a well bore. High speed photography in conjunction with the phutoelastic technique was used to observe the dynamic event of the prcpagaticn of cracks from an explosively loaded borehole in plastic models. The siudy revealed that crack initiation and early time propagation is entirely governed by the transient borehole pressure loading. The entire history of the borehole pressure is involvid in determining whether or not a srack initiates from a flaw site oll the borehole wall. The experimental observations in conjunction with the principles of wodern fracture mechanics vere utilized to formulate an analytical model of crack Initlation under explosive loading. The aralytical modeling was designed to ald in applying the modern concept of allored pulse loading to multiple fracture.

\section{ACKNO' ZEDGMENT}

The rork reported herein la a part of the Ph. $D$. requlrements of $K$. R. Y. Slaha and wae funded under DOE concract DE-AC2L-79MC-120010 frow Horgantown Energy Technology Center.

\section{REFERENCES}

Dally, J.H. ara Pournay, H.L., 1976, Fractura Contrel In Conscruction blesting - Kepore to the Nat fonal Selence Toundeclon, Unlveralcy of Maryland Contrace No. APR 73-07908-AOL

Grady, D.E. and Hollenbach, R.E., 1977, Eace-Controlling Pruceases in the Brice le Failure of Rock". Sandla Leb. Rept. 76-0659 to United Staces Enargy Research and Devolopaent Adalnacracton.

Iruln, G.R., 1958, FHandtuch der Phyolk VI, Flügge Ed, Springer, pp. $551-590$.

Roseminch, H.P., Ed., 1983, Rock Fracture Mechanlce, SpringerVerlay, Germany.

Shockey. D.A., Kalthoft. J.F. and Er'Lch, D.C., 1983, Evaluation of Dymaic Crack Inucablifty Criteria", Ine. Journ. of Fraceure, 22. 217-229.

SIehe, K.R.Y., Fournay. H.L., Garker, D.B. and Shuk.La, A., 1903, -Modal Seudies on Explous vely Driven Cracke Under Confinlng In-5itu Streneed". Proc. I Int l. Syop. Rock Fragaentation by Blast Ing. Lulia. Suedon.

Slohe, K.X.Y., Fourney, W.L. and Dick, R. D., 1984, -renploolvely Driven Fractura Inlelacton Under Confining In-Sicu Stresues: Phocorechanleo Lab. Rept., Unlv. of Marylund.

Harplnskl, N.R., Schmlde, R.A. and Norelicup, D.A., 19HO, "In-Steu

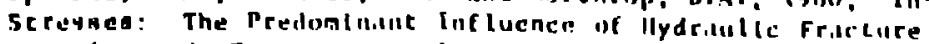

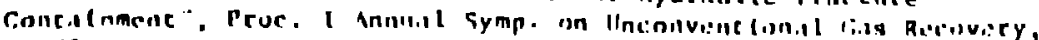
p. H3. 